\title{
Impact Of Information Technology On Tax Administration In Southwest, Nigeria
}

\author{
Olaoye Clement Olatunji (Ph. D) \\ Department of Accounting, Faculty of Management Science \\ Ekiti State University, Ado Ekiti \\ Kehinde Busayo Ayodele \\ Department of Accounting, Faculty of Management Science \\ Ekiti State University, Ado Ekiti
}

\begin{abstract}
This study examined the impact of information technology on tax administration in south west, Nigeria. It specifically investigated the effect of information technology on tax productivity and the relationship between information technology on tax implementation and tax planning. Descriptive research design was employed, of which questionnaire was used to gather data and analysed with multiple regression and pearson product moment correlation. The study revealed that information technology (Online Tax Filing-0TF, Online Tax Registration-0TR and Online Tax Remittance-OTRE) affect tax productivity with $-1.9 \%, 7.3 \%$ and $31.5 \%(p=0.85,0.526$ and 0.00$)$, there is relationship of $-5.9 \%(p=0.520), 9.7 \%(p=0.290)$ and $0.344(p=0.000)$ between $0 T$, OTR and OTRE on Tax Implementation-TAXIMP and $-3.8 \%(p=0.684), 14 \%(p=0.140)$ and $\mathbf{- 0 . 1 9 0}(\mathrm{p}=\mathbf{0 . 0 3 8}<0.05)$ relationship between OTF, OTR and OTRE on Tax PlanningTAXPLNN. The study concluded that information technology enhance the level of tax productivity and administration. It is therefore recommended that the respective agencies (federal, state and local government) responsible for tax collection should carry out one on one awareness in the form of seminars and sensitization of the process and suitability of information technology on tax administration.
\end{abstract}

Keywords: Tax Administration, Tax Productivity, Information Technology, Online Tax Filling, Online Tax Remittance, Online Tax Registration

\section{INTRODUCTION}

The use of automated systems has been proven to be capable of introducing massive efficiencies to business processes at a minimal cost (Wasao, 2014), due to the bureaucratic structure of government which is costly to manage with little or no result, tax authorities as an agency of government are turning to e-government led solutions like electronic tax filing (efiling) (Amabali, 2009), based on the arguments that it enhances the delivery of public services and fiscal profundity without incurring costly recurring overheads (Harrison \& Nahashon, 2015). United Nations (2007) stated that e-taxation is a process where tax documents or tax returns are submitted through the internet, usually without the need to submit any paper return; it encompasses the use of internet technology, the World Wide Web and Software for a wide range of tax administration and compliance purposes.

Electronic tax filing was first coined in United States, where her Internal Revenue Services (IRS) began offering tax return e-filing for tax refunds only (Muita, 2011). This has now grown to the level that currently approximately one out of every five individual taxpayers is now filing electronically. This however, has been as a result of numerous enhancements and features being added to the program over the years. Today, electronic filing has been extended to other developed countries like Australia, Canada, Italy United Kingdom, Chile, Ireland, Germany, 
France, Netherlands, Finland, Sweden, Switzerland, Norway, Singapore, Brazil, Mexico, India, China, Thailand, Malaysia and Turkey (Ramayah, Ramoo \& Amlus, 2006). Nigeria and other developing countries such as Uganda, Rwanda and Kenya have also embraced electronic filing of tax returns (Muita, 2011).

Dowe (2008) disclosed that tax authorities around the world are using electronic tax administration systems to interact with taxpaying public in tax collection, administration and compliance settings so as to improve effectiveness and efficiency in tax administration. Globally, previous studies on the suitability of information technology complied tax system have it that; a positive impact of automation system usage and the cost of tax administration, automation and effectiveness of revenue collection of Ghana Revenue Authority using a case study of customs division (Gidisu, 2012). Wasilewski cited in Muthama (2013) with focus on the economic development and taxation system by comparing the case of Brazil and Japan. Japan's experience demonstrated that a country does not need to postpone a real change in the tax structure until it achieves a high stage of development, while in Brazil; low-income taxpayers bear most of the tax burden.

Gasteiger (2011) indicated that automated system enhances administration with the provision of multiple scenarios that allow senior management in a multi-campus university system to generate multiple income scenarios, make well-informed decisions concerning the operation of their institution and timely calculation and allocation of resources to academic departments. In Kenya, Kioko (2012) indicated that the macro model performs better the variations in funds allocated to counties than the representative tax system, Kibe (2011) disclosed that planning for revenue collection can best be carried out by a system that combined spatial and attribute data management capabilities like geographical information systems, Harrison \& Nahashon (2015) with focus on small tax payers revealed that online tax system does affect tax compliance level, while Otieno, Oginda, Obura, Aila, Ojera \& Siringi (2013) stated that relationship existed between information systems and revenue collection efficiency and effectiveness and more so, there is a strong positive relationship between Internal Control Systems and revenue collection..

In Nigeria, Oseni (2015) concluded that there is no hiding place for tax evaders with the use of this modern technology since all potential taxpayers are captured by the system, but the use of ICT can be catastrophic if carelessly employed by both the tax payers and the tax administrators as scammers and hackers of the internet facilities can utilize the ignorance or the lax security of the system. Efunboade (2014) indicated that these emerging global infrastructures (Taxpayer Identification Number- TIN, Factual Accurate Complete TimelyProject FACT and Integrated System of Tax Administration- ITAS) could make it increasingly possible for eligible taxpayers to pay tax online anywhere and anytime.

In respect of the above, none of the studies had so far been carried out to investigate information technology, in terms of online tax filing, online tax registration and online tax remittance on the level of tax administration in terms of tax productivity, planning and implementation, which depicts existence of gap in literature. Although, Harrison \& Nahashon (2015) studied the effects of online tax system in terms of Online Tax Filing, Online Tax Registration and Online Tax Remittance, but it was based on tax compliance. Therefore, this study examines the impact of information technology on tax administration with interest on Southwest, Nigeria. 


\section{Information Technology}

\section{LITERATURE REVIEW}

Information technologies are tools, devices, and resources used to communicate, create, manage, and share information. They include hardware (computers, modems, and mobile phones), software (computer programs, mobile phone applications), networks (wireless communications, Internet) and basically concerned with the purpose of collecting, processing, storing and transmitting relevant information to support the management operations in any organizations (Adewoye \& Olaoye, 2014). It is a system that provides historical information on current status and projected information, all appropriately summarized for those having an institutions or forms (Adigbole \& Olaoye, 2013). Obi (2003) conceptualized that information technology is useful in the area of decision making as it can monitor by itself disturbances in a system, determine a course of action and take action to get the system in control. Adewoye \& Olaoye (2009) stated that the future planning information technology is built using the following; people, data processing, data communication, information system and retrieval and system planning.

\section{Tax Administration and Jurisdiction in Nigeria}

One thing is to make policies, rule and regulations in an attempt to attain a desired goal or objective and it is another thing to implement these policies, rules and regulations. The organs in charge of tax policy implementation in Nigeria are referred to as the administrative organ. Efficiency and effectiveness should be the watch word in designing a tax administration structure that will give the desired result. Kiabel \& Nwokah (2009) noted citing section 100 of the personal income tax decree, 1993 and amended by decree No 18 - finance (miscellaneous taxation provision decree 1998 that tax authority in the country are Federal Inland Revenue Service, State Board of Internal Revenue and Local Government Revenue Committee, together with the Joint Tax Board (JTB) and Joint State Revenue Committee.

The assignments of each are guided by constitutional provision. The federal constitution gave the federal government exclusive power to collect levies like personal income tax, companies income tax, petroleum profit tax, capital gains tax, excise duties, value added tax, custom duties (import duties and export duties), stamp duties, all with the exception of education tax are paid into the federation account for distribution among the three tiers of government in line with national constitution. States are given the power to collect personal income tax in respect to all taxable individuals except those of the armed forces personnel and individual personnel in the federal capital territory, right of occupancy fees on lands owned by the state government in the urban areas, market taxes and levies where state finance is involved, naming of street in the state capital, entertainment tax, survey fees, pools betting and other betting taxes among others, while the constitution gave the local government the function to collect license (trading) motor part dues, property tax, shops and kiosk rate, domestic animal license, tenement rates, on and off liquor license, slaughter slab fees, market tax, motor park levies, cattle tax, naming of street excluding those in the state capital, merriment and road closure levy, radio and television license fees, vehicle radio license fees, wrong parking charges, religious places establishment permit fees and signboard, advertisement permit fee and public convenience, sewage and disposal fees (Adeleke, 2011; 0jo, 2008).

\section{Intents of Tax Administration}

Ola (2001) conceptualized that taxation is a powerful and potential fiscal stabilizer employed by government of nations to plan development policies. The prime aim of tax administration in most nations of the world is essentially to generate revenue for government expenditure on social welfare such as provision of defense, law and order, health services and education. Revenue from taxation can also be spent on capital projects otherwise called consumer 
expenditure, creating social and economic infrastructure which will improve the social life of the people (Ariwodola, 2000).

Apart from this prime purpose of taxation, it can be used as a vital instrument in any nation's economy for promoting investment through the use of tax incentives and attractive tax exemptions which induce local and foreign investors in areas such as manufacturing of goods, export processing, and oil and gas, so also, taxation is usually used as an instrument for discouraging certain forms of antisocial behaviour in the society. Anti-social behaviour such as drinking of alcohol, smoking and pool betting can be controlled by the imposition of higher taxes on production of such goods (Ariwodola, 2000).

\section{Elements of a Viable Tax Administration System}

In respect to Olaoye (2008), a good tax system must be based on the following principles: efficacy: a viable tax system should advocates that ethics of professionalism transparency, accountability, probity and efficiency in tax collection; simplicity, the tax system and the tax law should be simple, flexible and adjustable, so as to compliance by tax payers and efficiency in operation by tax administrators; neutrality which implies that a good tax system should be free from any form of partiality; economy, tax system should make the economic situation better off and not worse off. It must not affect adversely the economic contribution of the tax payer. More so, the compliance costs to the tax payers and the administrative costs to the government must not negatively affect national output of taxes collected; equity, a viable tax system must not be arbitrary nor should the amount payable be influenced by prejudice or personal feelings; certainty, this stipulates that the time of payment, the manner of payment and the amount to be paid should be clear to the tax payer as well as the taxing authorities, convenience which relates to mode of payment and the timing. This principle stipulates that the time and manner of payments should not in convenience the tax payer; productivity which stipulates that a good tax system should be able to produce large amount of revenue.

\section{Tax Laws and Policies in Nigeria}

This refers to the embodiment of rules and regulations relating to tax revenue and the various kind of tax in Nigeria made by the legislative arms of government and constantly subjected to amendment. Ogbonna and Appah (2012); Kiabel \& Nwokah (2009); Ayodele (2006) stated that the following are some of the prevailing tax laws in Nigeria: Personal Income Tax Act (PITA) CAP P8 LFN 2004, Company Income Tax Act (CITA) CAP 60. LFN 1990 \& LFN 2004, Petroleum Profit Tax Act (PPTA) 2004 \& 2007, Value Added Tax (VAT) Act No 102 LFN 1993 \& 2004, Capital Gain Tax Act CAP 42 LFN 1990, Stamp Duties Act CAP 41 LFN 1990, Education Tax Act No 7 LFN 1993 \& 2004, Federal Inland Revenue Service Act 2004, Customs, Excise Tariffs, etc (Consolidation) Act 2004, National Sugar Development Act 2004; and National Automotive Council Act 2004, Information Technology Development Act 2007. Based on the report of the Presidential Committee on National Tax Policy (2008) the National tax policy provides a set of rules, modus operandi and guidance to which all stakeholders in the tax system most subscribe. The formulation of tax administration policy in the country is based on the responsibility of the Federal Inland Revenue Service (FIRS), Customs, Nigerian National Petroleum Corporation (NNPC), National Population Commission (NPC), and other agencies but under the guidance of the National Assembly (Presidential committee on National tax policy, 2008). Recent reforms in tax laws in country resulted into the promulgation of Tertiary Education Trust Fund Act 2011, Personal Income Tax Act and Federal Capital Territory Act 2015. 


\section{Perquisites for Implementing Electronic Taxation System}

Dowe (2008) argued that the basic prerequisites for implementing successful e-filing and e payment systems are: a reliable and accessible internet service; cooperative financial institutions; an IT oriented public; and adequate financing to set up the appropriate infrastructure in tax offices. Ideally, the setting of an e-filing and e-payment system should form part of a comprehensive IT design, development and implementation strategy, which correlates the view of Muita (2011) that for e-filing to effectively take off; skills, infrastructure and a conducive business environment are needed.

The implementation process for electronic tax systems begins with the development of a strategic business plan - documenting the ideas and actions, desired outcomes and the time frame for each component, taking into account the strengths and weaknesses of the tax administration and environmental opportunities and threats. The plan should also document the implementation strategy including the implementation approach. Many countries have taken a gradual approach by allowing voluntary e-filing and e-payment for select segments of the taxpayer base, e.g. individuals or companies only, in the initial stages to allow for live testing of the system. After testing is complete filing becomes mandatory for some taxpayers, e.g. companies (Dowe, 2008).

In addition to the above, an efficient e-taxations system needs constant electricity supply, organized seminars for tax payers and tax officers on the usage, secured, user friend and easy assessable website and law.

\section{Benefits of Adopting Information Technology in Tax Administration}

Dzidonu (2012) itemized the benefit of using information technology to manage the operations and delivery of public sector institutions to include: improvement in administrative efficiency, effectiveness and productivity, improvement in service delivery, reduction in administrative, operational and transactional costs of public and provision of access to information at a reduced cost. In relation to taxation, significance of the use of IT is infinite, some of which are; facilitates a reducing in the overhead cost of managing the agencies of government responsible for tax administration, instant computation of tax liability from the use of online tax calculator, reduced cost of registering tax payers and instant generation of tax identification number, reducing in staff-taxpayers collusion as regards tax liability, reduction in fraudulent activities of tax collectors in the aspect of non-remittance of tax received from tax payers and boost the revenue of government in terms of reduction in expenses (administrative, overhead and transactional) and corrupt practices.

Adewoye, Ademola, Afolabi \& Oyeleye (2013) opines that the anticipated benefits of implementing an information technology system include improvements in productivity, better profit performance, and a higher degree of accuracy of information. Productivity typically improves in organizations which implement information technology, although there can be some loss of productivity during the "learning curve." (Adewoye \& Olaoye, 2014).

\section{Pitfalls of Adopting Information Technology in Tax Administration}

Ideally, the adoption of IT-facilities in administering taxation can leads to indifference attitude on the payment of taxes, garbage-in-garbage-out, that is imputation of wrong figures that will lead to wrong calculation of tax liability by online tax calculator, poor internet facility, poor electricity to power host server, high cost of maintenance of ICT facilities, lack of technical Know-how by tax administering agencies, high level of illiteracy among lower income earners that characterized the population, incidence of internet hackers. So also, Oseni (2015) opined that the use of ICT can be catastrophic if carelessly employed by both the tax payers and 
the tax administrators as scammers and hackers of the internet facilities can utilize the ignorance or the lax security of the system.

\section{Conceptual Framework}

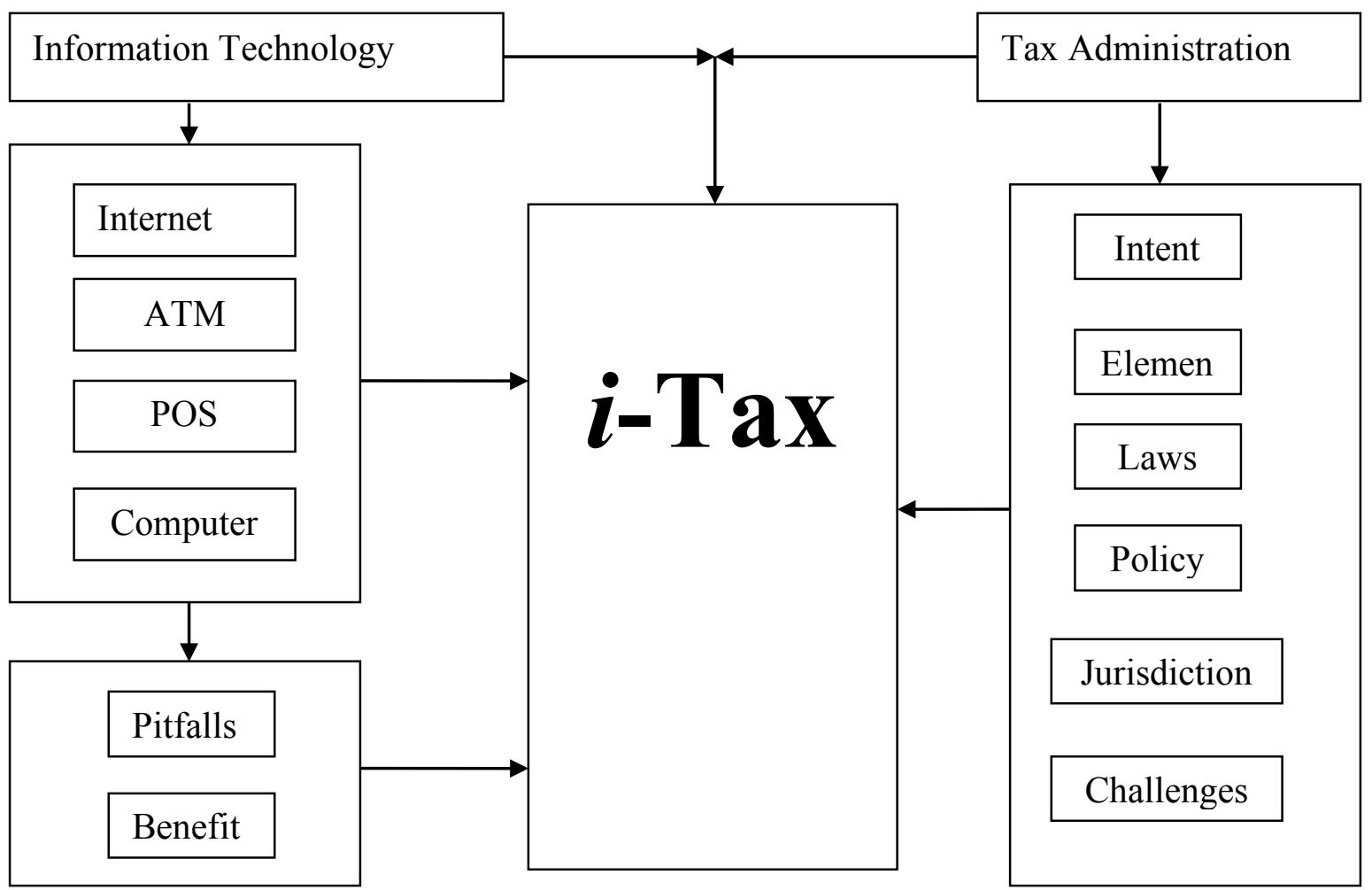

Fig1: i-Tax connectivity

\section{METHOD}

The study was carried out in Southwest, Nigeria which comprised of the following States Ekiti, Ondo, Oyo, Osun, Ogun and Lagos State. The study adopted descriptive survey design and population of the study which consisted of all members of staff in the agencies of government (federal and state) responsible for tax administration in Southwest, Nigeria, while sample which comprised of members of staff excluding unprofessional cadre (gatemen, clerical staffs, messengers) was purposively selected.

Questionnaire as research instrument, while face and content validity and test-retest technique was respectively used to measure its validity and reliability. It was later administered to a total of one hundred and twenty (120) members of staff of the stated agencies. In analyzing the data collected, inferential statistics in the form of multiple regression and pearson product moment correlation were used. So also, the following diagnostic test; variance inflation factor (VIF), White Heteroskedasticity test and Breush-Godfrey LM test were conducted in other to ensure reliability and validity of the results.

\section{Model Specification}

The model of the study stated below was based on the modification of model specified by Harrison \& Nahashon (2015) on the effects of online tax system in terms of online tax filing, online tax registration and online tax remittance on tax compliance.

Tax Administration (TAXAD) is a function of Information Technology (IT) 
Tax Administration (TAXAD) is measured with indicators and variables given as follows: TAXAD = Tax Collectivity-TAXCOLAD, Tax Implementation-TAXIMP, Tax Planning- TAXPLNN

while, Information Technology (IT) is measured with indicators and variables given as follows is measured with:

IT= Online Tax Filing-OTF, Online Tax Registration-OTR, Online Tax Remittance-OTRE

Therefore:

$$
\text { TAXCOLAD+TAXIMP+TAXPLNN }=\beta+\mathrm{a}_{1} \mathrm{OTF}+\mathrm{a}_{2} \mathrm{OTR}+\mathrm{a}_{3} \text { OTRE }+\mu
$$

The model is specified in a log-linear estimation form as;

$\log$ TAXCOLAD $+\log$ TAXCOLAD $+\log$ TAXIMP $+\log$ TAXPLNN $=\beta 0+\mathrm{a}_{1} \log$ OTF $+\mathrm{a}_{2} \log$ OTR $+\mathrm{a}_{3} \log$ OTRE $+\mu \mathrm{t} \ldots \mathrm{i}$

DATA ANALYSIS AND INTERPRETATIONS

Table I: Regression Analysis on Information Technology and Tax Collectivity Coefficients

\begin{tabular}{|c|c|c|c|c|c|c|}
\hline \multirow{2}{*}{\multicolumn{2}{|c|}{ Model }} & \multicolumn{2}{|c|}{ Unstandardized Coefficients } & \multirow{2}{*}{$\begin{array}{c}\text { Standardized } \\
\text { Coefficients } \\
\text { Beta } \\
\end{array}$} & \multirow[t]{2}{*}{$\mathrm{T}$} & \multirow[t]{2}{*}{ Sig. } \\
\hline & & B & Std. Error & & & \\
\hline \multirow{4}{*}{1} & (Constant) & 7.933 & 1.252 & & 6.336 & .000 \\
\hline & OTF & -.019 & .102 & -.021 & -.190 & .850 \\
\hline & OTR & .073 & .114 & .064 & .636 & .526 \\
\hline & OTRE & .315 & .055 & .522 & 5.780 & .000 \\
\hline \multicolumn{7}{|c|}{ Model Summary } \\
\hline \multicolumn{2}{|c|}{ Model } & $\mathrm{R}$ & R Square & $\begin{array}{c}\text { Adjusted R } \\
\text { Square }\end{array}$ & \multicolumn{2}{|c|}{$\begin{array}{l}\text { Std. Error of the } \\
\text { Estimate }\end{array}$} \\
\hline \multicolumn{2}{|l|}{1} & $.525^{\mathrm{a}}$ & .275 & .256 & & 1.37185 \\
\hline
\end{tabular}

Source: Authors computation (2017)

a. Predictors: (Constant), OTRE, OTR, OTF

a. Dependent Variable: TAXCOLAD

In the table I, it could be inferred that if the explanatory variables (OTRE, OTR, OTF) are held constant, the explained variable (TAXCOLAD) will be 7.933 unit better off, which implies that in a situation where there is no adoption of IT on the administration of tax, tendency for efficiency in tax administration in the country will be 7.938. The unstandardised beta coefficient of online tax filing-OTF is -.019 ( $\mathrm{S} . \mathrm{E}=.102, \mathrm{t}=-.190$ and $\mathrm{p}>0.05$ ). This depicts that an increase in the use of OTF results to $1.9 \%$ insignificant inverse effect on tax collectivity in the country, this contradict the conclusion of Efunboade (2014) that emerging global infrastructures (Taxpayer Identification Number- TIN, Factual Accurate Complete TimelyProject FACT and Integrated System of Tax Administration- ITAS) could make it increasingly possible for eligible taxpayers to pay tax online anywhere and anytime. Online tax registration indicated $0.073(\mathrm{p}>0.05)$ insignificant impact on TAXCOLAD, which implies that a unit increase in the use of IT facilities for tax payers registration results to $7.3 \%$ insignificant impact on tax collection.

The above findings can be ascribed to the pitfalls associated with the adoption of IT-facilities in administering taxation which includes indifference attitude on the payment of taxes, garbage- 
in-garbagge-out, that is imputation of wrong figures that will lead to wrong calculation of tax liability by online tax calculator, poor internet facility, poor electricity to power host server, high cost of maintenance of ICT facilities, lack of technical Know-how by tax administering agencies, high level of illiteracy among lower income earners that characterized the population, incidence of internet hackers and view of Oseni (2015) that the use of ICT can be catastrophic if carelessly employed by both the tax payers and the tax administrators as scammers and hackers of the internet facilities can utilize the ignorance or the lax security of the system

Online tax remittance of tax liability by tax payers-OTRE, depict significant impact of 31.5\% $(\mathrm{p}<0.05)$ on tax collectivity, which is in tandem with the findings of; Harrison \& Nahashon (2015) that online tax system does affect tax compliance level among small taxpayers, Seelmann, Lerche, Kiefer \& Lucante (2011) which concluded that computerization of tax and revenue authorities contribute to reaching the goal of good (financial) governance, by improving accountability and transparency of the revenue authorities. So also, Oseni (2015) which revealed that modern technology reduce tax evaders since all potential taxpayers are captured by the system and thus enhance the efficiency in collectivity of taxes. This correlates the view of Adewoye, Ademola, Afolabi \& Oyeleye (2013) which disclosed that the anticipated benefits of implementing an information technology system include improvements in productivity, better profit performance, and a higher degree of accuracy of information. Productivity typically improves in organizations which implement information technology, although there can be some loss of productivity during the "learning curve." (Adewoye \& Olaoye, 2014).

In addition, the model summary shows that there is $52.5 \%$ relationship ( $\mathrm{r}$ ) between information technology and tax collectivity- TAXCOLAD. The $\mathrm{R}^{2}$ shows that the predictors of information technology (OTRE, OTR and OTF) explains 0.275 variations in tax collectivity. In respect of the adjusted $\mathrm{R}^{2}$ which takes into the cognizance of the error term, signifies that adoption of information technology tools explains $25.6 \%$ variation in the TAXCOLAD while the remaining $68.1 \%$ are explained by others factors excluding information technology which are not captured in the study such as tax penalty, tax payers' knowledge on tax laws, tax audit, tax drive. 
Table II: Relationship between Information Technology and Tax Implementation Correlations

\begin{tabular}{|ll|r|r|r|r|}
\hline & & \multicolumn{1}{|c|}{ TAXIMP } & OTF & \multicolumn{1}{c|}{ OTR } & \multicolumn{1}{c|}{ OTRE } \\
\hline \multirow{4}{*}{ TAXIMP } & Pearson Correlation & 1 & -.059 & .097 & $-.344^{* *}$ \\
& Sig. (2-tailed) & & .520 & .290 & .000 \\
& $\mathrm{~N}$ & 120 & 120 & 120 & 120 \\
& Pearson Correlation & -.059 & 1 & $.604^{* *}$ & $.457^{* *}$ \\
OTF & Sig. (2-tailed) & .520 & & .000 & .000 \\
& $\mathrm{~N}$ & 120 & 120 & 120 & 120 \\
& Pearson Correlation & .097 & $.604^{* *}$ & 1 & .149 \\
OTR & Sig. (2-tailed) & .290 & .000 & & .105 \\
& $\mathrm{~N}$ & 120 & 120 & 120 & 120 \\
& Pearson Correlation & $-.344^{* *}$ & $.457^{* *}$ & .149 & 1 \\
OTRE & Sig. (2-tailed) & .000 & .000 & .105 & \\
& $\mathrm{~N}$ & 120 & 120 & 120 & 120 \\
\hline
\end{tabular}

Authors computation 2017

**. Correlation is significant at the 0.01 level (2-tailed).

The results as presented in table 2 revealed that there is $-5.9 \%(p=0.520)$ insignificant correlation between online tax filing-OTF and tax implementation-TAXIMP which implies that a growth the use of online tax filing by tax payers will result to a reduction in tax implementation. Online tax registration by tax payers and tax implementation had a 9.7\% $(\mathrm{p}=0.290)$ positive correlation, online tax remittance by tax payers of tax liability has significant inverse association of $0.344(\mathrm{p}=0.000)$ with tax implementation in the country. The above result is concurrence with the conclusion of Sagas, Nelimalyani and Kimaiyo (2015) in Gekonge \& Wallace (2016) that electronic tax register machines have helped to curb cases of tax evasion ETRs have helped increase revenue collection due to their efficient nature.

Table III: Relationship between Information Technology and Tax Planning Correlations

\begin{tabular}{|ll|r|r|r|r|}
\hline & & TAXPLNN & OTF & OTR & \multicolumn{1}{c|}{ OTRE } \\
\hline \multirow{3}{*}{ TAXPLNN } & Pearson Correlation & 1 & -.038 & .140 & $-.190^{*}$ \\
& Sig. (2-tailed) & & .684 & .126 & .038 \\
& $\mathrm{~N}$ & 120 & 120 & 120 & 120 \\
& Pearson Correlation & -.038 & 1 & $.604^{* *}$ & $.457^{* *}$ \\
OTF & Sig. (2-tailed) & .684 & & .000 & .000 \\
& $\mathrm{~N}$ & 120 & 120 & 120 & 120 \\
& Pearson Correlation & .140 & $.604^{* *}$ & 1 & .149 \\
OTR & Sig. (2-tailed) & .126 & .000 & & .105 \\
& $\mathrm{~N}$ & 120 & 120 & 120 & 120 \\
& Pearson Correlation & $-.190^{*}$ & $.457^{* *}$ & .149 & 1 \\
& Sig. (2-tailed) & .038 & .000 & .105 & \\
& $\mathrm{~N}$ & 120 & 120 & 120 & 120 \\
\hline
\end{tabular}

Source: Authors computation 2017

*. Correlation is significant at the 0.05 level (2-tailed).

**. Correlation is significant at the 0.01 level (2-tailed).

The results as presented in table 3 shows that there is $3.8 \%(p=0.684>0.05)$ insignificant inverse relationship between online filing of tax returns by tax payers (OTF) and tax planning 
(TAXPLNN) which implies that a growth the use of online tax filing by tax payers will result to a reduction in tax planning. Online tax registration by tax payers and tax planning had a 14\% $(p=0.140>0.05)$ correlation, online tax remittance by tax payers of tax liability has significant inverse link of $0.190(\mathrm{p}=0.038<0.05)$ with tax planning.

\section{Diagnostic Test}

The following diagnostic test; variance inflation factor (VIF), White Heteroskedasticity test and Breush-Godfrey LM test were conducted in other to ensure reliability and validity of the above results. The results of the diagnostic test were thus presented below:

Table IV: Variance Inflation Factor Test Coefficients $^{\mathbf{a}}$

\begin{tabular}{|c|c|c|c|}
\hline \multirow{2}{*}{\multicolumn{2}{|c|}{ Model }} & \multicolumn{2}{|c|}{ Collinearity Statistics } \\
\hline & & Tolerance & VIF \\
\hline \multirow{3}{*}{1} & OTF & .497 & 2.011 \\
\hline & OTR & .614 & 1.628 \\
\hline & OTRE & .766 & 1.305 \\
\hline
\end{tabular}

Source: Authors computation 2017

Based on the result in the table IV above which showed the result for the presence or otherwise of multicollinearity among the variables used in this study, the result indicated that all the variables used in the study are relevant to the study since the VIF factors of each (OTF, OTR, ORE) is below the benchmark of 10 and thus indicates the absence of multicollinearity in model.

Table V: Serial Correlation Test

\begin{tabular}{|l|l|}
\hline Breusch-Godfrey Serial Correlation LM Test: \\
\hline F-statistic & 15.095818 \\
\hline Unadjusted R-squared & 0.116036 \\
\hline p-value = P(F(1,115) > 15.0958) & 0.000171 \\
\hline $\mathrm{P}($ Chi-square(1) $>13.9243)$ & 0.00019 \\
\hline
\end{tabular}

Authors computation 2017

Table $\mathrm{V}$ above shows that the F-statistic and Unadjusted R-squared values of 15.095818 and 0.116036 with p-values of 0.000171 and 0.00019 respectively indicates the presence of autocorrelation in model since the F-statistic and Unadjusted R-squared with p-values of 0.000171 and 0.00019 are lesser than the critical values at $5 \%$ level of significance. Thus, we can conclude that there is presence of autocorrelation in the model used for the study.

Table VI: Heteroskedasticity Test

\begin{tabular}{|l|l|}
\hline Heteroskedasticity Test: White \\
\hline F-statistic & 62.089868 \\
\hline Unadjusted R-squared & 0.517416 \\
\hline $\mathrm{P}($ Chi-square(9) > 62.089868) & 0.00 \\
\hline
\end{tabular}

Authors computation 2017 
The table above shows that the F-statistic and Unadjusted R-squared values of 62.089868 and 0.517416 with p-value of 0.00 respectively indicates the presence of heteroskedasticity in model1 since the F-statistic and Unadjusted R-squared with p-values of 0.00 is lesser than the critical values at 5\% level of significance. Thus, we can conclude that there is presence of heteroskedasiticity in the model

\section{CONCLUSION AND RECOMMENDATIONS}

Based on the findings of the study, It is mainly concluded that information technology enhance the level of productivity in tax collectivity and administration. Specifically; online filing and remittance of tax returns by tax payers' are inversely associated with tax planning and implementation by tax administrative agencies. The adoption of information technology in the registration of eligible and potential tax payers portrays efficiency in tax planning and implementation which in turn ensures ease collectivity of tax returns.

In respect of the research findings, the study recommends that: filing of tax online should be monitored and controlled because of its adverse effect on planning and implementation of tax collectivity; respective agencies (federal, state and local government) responsible for tax collection should sensitize eligible and potential tax payers on the process and suitability of online tax registration by tax payers in other to enhance its impact on tax administration in the country; online tax remittance should be encourage among tax payers because it enhance flexibility in tax collection, but it must be controlled with manual remittance due to its inverse impact on planning and implementation of tax administration; and a replica of the study should be carried out in other parts of the country in other to re-validate and test the applicability of the findings in them.

\section{References}

Ariwodola, J. T. (2000). Personal Taxation in Nigeria Including Capital Gains Tax and Capital Transfer Tax. Lagos. Jaja publishing Ltd, 12-17.

Adeleke, S. (2011). Taxation, Revenue allocation and fiscal Federalism in Nigeria: issues, challenges and policy options. Economic Annals, 6, 189.

Adewoye, J. O, Ademola, A. O, Afolabi O.D \& Oyeleye, O. (2013). Performance impact of Information and Communication Technology (ICTs) on women entrepreneurs in South Western Nigeria. Available online at www.elixirpublishers.com (Elixir International Journal)

Adewoye, J. O. \& Olaoye, C. O. (2009). Accounting Information Technology, Ijagbo/Offa, Kwara State.

Adewoye, J. 0. \& Olaoye, C. O. (2014). Usage of information technology to enhance professional Productivity among accountants in Ekiti State. International Journal of Accounting and Financial Management Research (IJAFMR)),4(2),7-18.

Adigbole, E.A \& Olaoye, C.O. (2013). The application of Information Technology on Administrative Efficiency in Nigeria Universities. A case study of five selected Universities in Ekiti state, Reseach Journal of management, 1(1). Available on www.researchjournali.com

Amabali, A.R. (2009). E-Government Policy: Ground issues in e-filing system, European Journal of Social Sciences 21(13). 189-45.

Ayodele, 0.(2006).Tax Policy Reform in Nigeria. World Institute for Developmental Econmic Research(WIDER).Research PAPER,3

Dzidonu, C.K. (2012). Using Information and Communication Technology (ICT) in Managing National Resources. Paper Presented at the $7^{\text {th }}$ Internal AuditForum, Accra

Dowe, D.E., (2008). E-Filing and E-Payments - The Way Forward, Paper presented at Caribbean Organization of Tax Administration (COTA) General Assembly, Belize City,

Efunboade, A. O. (2014). Impact of ICT on Tax Administration in Nigeria. Computer Engineering and Intelligent Systems, 5(8), 26-29

Gasteiger, D. W. (2011). An automated enrolment projection system, (Unpublished degree of Doctor of Philosophy 
thesis, Ontario Institute for Studies in Education, University of Toronto)

Gekonge, J .M., \& Wallace, A. (2016). Effects of Electronic- Tax System on the Revenue Collection Efficiency of Kenya Revenue Authority: A Case of Uasin Gishu County. Imperial Journal of Interdisciplinary Research (IJIR), 2(4), 815-827.

Gidisu, T. E. (2012). Automation System Procedure of the Ghana Revenue Authority on the Effectiveness of Revenue Collection: A Case Study of Customs Division, Unpublished MBA Thesis, Kwame Nkrumah University of Science and Technology

Harrison, M. M. \& Nahashon, K. (2015). Effects of online tax system on tax compliance among small taxpayers in Meru County, Kenya. International Journal of Economics, Commerce and Management,3(12), 280

Kiabel, B. D. \& Nwokah, N. G. (2009). Boosting Revenue Generation by State Government in Nigeria: The Tax Consultants Option revisited. European Journal of social sciences 8(4) 532-539.

Kibe, E. M. (2011). Use of geographical information systems to enhance revenue collection in Local Government. (Unpublished MBA Project, University of Nairobi).

Kioko, B. K. (2012). Comparison between representative tax system and macro basis for revenue equalization systems in Kenya. (Unpublished MBA Project, University of Nairobi).

Muita, E.W. (2011). Factors that Influence Adoption and Use of E-Filing System of Kenya Revenue Authority Among The Large Taxpayers, (Unpublished MBA Project submitted to the JKUAT Nairobi Central Business District Campus).

Muthama, J (2013). The effects of revenue system modernization on revenue collection at Kenya revenue. (M.Sc., Research Project, University of Nairobi).

Obi (2003). Educational Management: theory and practice, Enugu: JAMOE Nigeria enterprises.

Ogbonna, G.N. \& Appah, E. (2012). Impact of Tax Reforms and Economic Growth of Nigeria: A Time Series Analysis. Current Research Journal of Social Sciences, 4(1), 62-68.

Ojo, S. (2008). Fundamental Principles of Nigerian Tax. Sagribra Tax Publication, Lagos.

Olaoye, C. O. (2008). Concepts of Taxation. Offa: Clemart Publishing.

Oseni, M. (2015). Sustenance of Tax Administration by Information and Communications Technology in Nigeria. Archieves of Business Research, 4(1), 47-54.

Otieno, O.C., Oginda, M., Obura, J. M., Aila, F. O., Ojera \& Siringi, E. M. (2013). Effect of Information Systems on Revenue Collection by Local Authorities in Homa Bay County, Kenya. Universal Journal of Accounting and Finance, 1(1), 29-33.

Presidential Committee on National Tax Policy (2008). Draft Document on the National Tax Policy. Available from: http//www.scribd.com/doc/10063735/National-Tax-Policy-Draft-updated.

Seelmann, J., Lerche, D., Kiefer, A. \& Lucante, P. (2011), Benefits of a computerized integrated system for taxation: iTax case study. A handbook for practitioners based on GIZ tax sector experience in Tanzania and the Philippines http://www.taxcompact.net/documents/ITC_iTax-case-study.pdf

UN, (2007), Benchmarking e-government: A Global Perspective, retrieved from http://www.unpal.un.org/intradoc/groups/public/documents/april 2013

Wasao, D. (2014), The effect of online tax system on tax compliance among small taxpayers. University of Nairobi. 